\title{
PENGARUH PENDAPATAN PREMI, HASIL UNDERWRITING, HASIL INVESTASI DAN RISK BASED CAPITAL TERHADAP LABA PERUSAHAAN ASURANSI UMUM SYARIAH
}

\author{
Nurul Hidayati Nasution ${ }^{1}$; Satria Tri Nanda ${ }^{2}$ \\ Fakultas Ekonomi Universitas Lancang Kuning \\ Jln. D.I. Panjaitan KM 8 Rumbai Pekanbaru \\ E-mail : satriatrianda@unilak.ac.id \\ diterima: 16/1/2020; direvisi: 5/2/2020; diterbitkan: 26/3/2020
}

\begin{abstract}
This study was conducted to test the effect of premium income, underwriting results, investment income and risk based capital on general syariah insurance companies' profit. The method applied in this study was quantitative method. The population included the insurance companies registered at Otoritas Jasa Keuangan ( OJK) in 2011-2015. The samples of this study were 1 syariah insurance companies and 14 unit syariah Insurance companies selected using purposive sampling technique. The types of data used on this study was secondary data. The method of data collection applied was documentation method and panel data regression using a computer program Eviews 7.0. The results of the analysis showed that: (1) premium income had significant positive effect on insurance profit, (2) underwriting results had significant negative effect on insurance profit, (3) inverstment income had negative significant effect on insurance profit, (4) risk based capital had positive significant effect on insurance profit.
\end{abstract}

Keywords: Premium Income, Underwriting Results, Risk Based Capital, Insurance

\section{PENDAHULUAN}

Kehidupan modern saat ini sangat berpengaruh besar terhadap perkembangan dunia global, sejalan dengan pengaruh pola kehidupan tersebut maka berkembang pula perekonomian dan meningkatnya jenis dan berbagaimacam kebutuhan barang dan jasa. Dengan perkembang prekonomian dan teknologi akan memunculkan kekhawatiran manusia akan adanya peluang resiko yang dapat membahayakan harta benda bahkan diri seseorang serta risiko lainnya yang dapat menghilangkan manfaat atau keuntungan. Resiko dapat disebabkan kelalaian, orang pribadi dan lingkungan usaha.

Perusahaan non keuangan atau asuransi adalah perusahaan yang memberi janji kepada tertanggung untuk melindungi diri seseorang atau aset dari kerugian yang mungkin akan terjadi
(Kasmir; 2012). Pengertian lainnya menyebutkan bahwa perusahaan asuransi adalah suatu instansi keuangan non bank yang di design untuk menampung risiko, yang pada hakikat nya menjual produk jasa proteksi kepada konsumen atau masyarakat (Sartono; 2014).

Menurut UU RI No. 40 Tahun 2014 mengenai Perasuransian dari sudut pandang sistem, dibagi menjadi: (1) Asuransi konvensional. Prinsip operasional dari asuransi konvensional yaitu pemindahan resiko (transfer risk) dari nasabah asuransi kepada perusahaan asuransi (2) Asuransi syariah (takaful), prinsip operasional dari asuransi syari'ah adalah tolong menolong (share risk). Berdasarkan produk yang dipasarkan, dibanding asuransi berbasis konvensional asuransi syariah lebih menguntungkan. Adanya pembagian profit merupakan salah satu keutamaan Asuransi syariah terlebih karena adanya dana tabarru' atau 
dana kumpulan (Monitor; 2018). Namun, saat ini di Indonesia asuransi lebih banyak yang menggunakan sistem konvensional, khususnya asuransi umum. Dengan jumlah penduduknya yang mayoritas muslim, seharusnya menjadi potensi besar untuk berkembangnya asuransi syariah di Indonesia.

Hal lain yang menjadi masalah adalah laba perusahaan asuransi yang mengalami fluktuasi, semenjak 2014 terdapat penurunan dana himpunan dari masyarakat, bahkan beberapa diantaranya mengalami kerugian. Seperti kasus PT Asuransi takaful umum tercatat 4 tahun berturut mengalami kerugian 2014-2017. Dengan modal Rp 150 miliar asuransi umum takaful didirikan atau tepatnya pada tahun 1994. Dan pasa saat tersebut perusahaan terindikasi akan masuk dalam perusahaan beku kegiatan operasi (BKO). Hal tersebut semakin memburuk ketika diakhir 2014 premi sama sekali tidak tumbuh dan perusahaan mengalami bleeding (voaislam.com,2018).

\section{TINJAUAN PUSTAKA}

Pendapatan premi adalah Menurut Sula (2014; 311) premi atau dalam istilah fiqih muamalah adalah almusahamah atau dana kontribusi. Dalam Asuransi syariah pendapatan premi berarti dan ayang terdiri atas dana tabungan dan dana tabbaru' dimana dana tabbaru' merupakan sumbangan atau derma yang di berikan secara ikhlas oleh peserta kepada peserta lain yang mengalami musibah atau biasa disebut pembayaran santunan klaim, sedangkan dana tabungan merupakan dana yang dicadangkan untuk investasi dan akan mendapatkan bagi hasil sesuai prinsip mudharabah (Juwita :2017). Oleh karena itu, tinggi nya laba yang dihasilkan dari pengelolaan asuransi tidak lepas dari meningkatnya pendapatan premi adalah salah satu faktor paling menentukan.

Underwriting adalah proses prakiraan terhadap calon tertanggung atau aset yang akan di cover, untuk menetapkan (1) layak kah calon tertanggung mendapat proteksi dan jika dapat (2) menyesuaikan golongan resiko yang sesuai bagi tertanggung (Sula; 2014; 183). Underwriting result or underwriting income is the eraned premium remaining, it is the difference between tabbaru' premiums and claims paid out and expanses a periode of time, but if underwriting loss of premium its mean deficit Underwriting (Juwita;2017). Asuransi akan mendatangkan laba seiring dengan baiknya pengelolaan underwriting disuatu perusahaan asuransi.

Hasil investasi adalah kegiatan menanamkan modal seperti dan harta dengan tujuan imbalan keuntungan pembagian hasil investasi yang diserahkan kepada pemilik dana dalam hal ini yaitu pengelola dan peserta asuransi (Supiyanto; 2015; 33), sehingga semakin baik pengelolaan dana investasi maka akan semakin mendatangkan laba.

$$
\text { Risk Based Capital (RBC) }
$$

merupakan parameter utama dalam penilaian kesehatan finansial perusahaan dengan penggunaan rasio solvabilitas terhadap resiko yang ditanggung. Sesuai surat keputusan menteri keuangan republik indonesia tentang Keuangan Perusahaan Asuransi dan Reasuransi nomor 424/KMK.06/2003 bahwa setiap perusahaan asuransi wajib memiliki RBC paling rendah $120 \%$ yang berarti bahwa hutang perusahaan dan biaya setiap resiko asuransi yang di tanggung wajib ditutupi dengan minimal 20\% lebih besar dari aset perusahaan. Rasio RBC yang tinggi mencerminkan kesehatan finansial dari perusahan asuransi yang baik. Sehingga laba yang dihasilkan oleh perusahaan asuransi akan semakin meningkat (Bogar; 2016; 65). 
Pada penelitian ini akan di observasi lebih mendalam mengenai premium income, underwriting result, investment income and risk based capital sebagai faktor yang berpengaruh terhadap laba perusahaan asuransi umum khususnya pada asuransi syariah yang ada di Indonesia selama periode 20132017 listing di OJK ( Otoritas Jasa Keuangan).

Berdasarkan urairan diatas maka dapat diambil rumusan masalah Apakah pendapatan premi berpengaruh signifikan terhadap laba perusahaan asuransi umum syariah? (2) Apakah hasil underwriting berpengaruh signifikan terhadap laba perusahaan asuransi umum syariah? (3) Apakah hasil investasi berpengaruh signifikan terhadap laba perusahaan asuransi umum syariah? (4) Apakah risk based capital berpengaruh signifikan terhadap laba perusahaan asuransi umum syariah? (5) Apakah pendapatan premi, hasil underwriting, hasil investasi dan risk based capital secara bersama-sama berpengaruh signifikan terhadap laba perusahaan asuransi umum syariah?

Pendapatan premi adalah sujumlah uang yang diberikan untuk membeli sebuah kontrak perjanjian pertanggungan asuransi yang di tuangkan dalam polis asuransi. Berdasarkan penelitian yang dilakukan oleh Sastri dkk (2017) memaparkan bahwa income premium have a significant and positive impact on insurance companies'profit. Berdasarkan pemaparan tersebut, hipotesis pertama dalam penelitian ini adalah :

$\mathrm{H} 1$ : Premium income had significant on generalsyariahinsurance companies'profit.

Hasil underwriting kelebihan premi dari pengurangan premium income dan biaya santunan (klaim dan ujrah) yang mencerminkan laba/rugi
(Sastri dkk; 2017). Ini mencerminkan jika asuransi dikelola dengan baik maka kemungkinan resiko yang dipindahkan keperusahaan akan mendatangkan laba. Penelitian yang dilakukan oleh Dipoyanti (2014) membuktikan bahwa hasil underwriting berpengaruh negatif signifikan terhadap laba asuransi. Berdasarkan pemaparan tersebut maka second hypothesis dalam penelitian ini adalah :

$\mathrm{H} 2$ : Underwriting result had significant on general syariah insurance companies 'profit.

Hasil investasi adalah kegiatan menanamkan modal seperti dan harta dengan tujuan imbalan keuntungan dan pembagian hasil investasi yang diserahkan kepada pemilik dana dalam hal ini yaitu pengelola dan peserta asuransi (Supiyanto; 2015; 33). Penelitian yang dilakukan oleh Sari (2017) memaparkan hasil investasi berpengaruh positif signifikan terhadap laba asuransi. Dari hasil penelitian tersebut maka the third hypothesis dalam penelitian ini adalah :

$\mathrm{H} 3$ : Invesment income had significant on generalsyariahinsurance

companies'profit.

RBC merupakan ukuran kesehatan financial perasuransian. Semakin tinggi rasio kesehatan $\mathrm{RBC}$ maka akan mendatangkan laba yang baik dan hal tersebut mencerminkan kesehatan finansial atau keuangan perusahaan asuransi tersebut seiring dengan hal tersebut maka laba yang di peroleh juga akan meningkat (Bogar; 2016; 65). Dari research yang dilakukan oleh Sastri dkk (2017) memaparkan risk based capital berpengaruh positif signifikan terhadap laba asuransi.

H4: Risk based capital had significant on generalsyariahinsurance

companies'profit

Dari pemaparan diatas dapat diambil hipotesis secara simultan bahawa: H5 Premium income, underwriting result, 
Jurnal Ilmiah Ekonomi dan Bísnis

Vol. 17. No.1, Maret 2020 : 41-55

EISSN : $2442-9813$

ISSN : $1829-9822$

Invesment income and risk based capital together had significant on general syariah nsurance companies'profit.

\section{METODE PENELITIAN}

Penelitian atau reserch ini dilakukan $d$ engan meninjau data skunder, berupa financial report dari perusahan general syariah insurance yang diterbitkan pada website perusahaan asuransi yang diteliti. Reserch ini termasuk dalam jenis kuantitatif yaitu dengan penggunaan angka angka, dan dengan melakukan peninjauan terhadap laporan keuangn yang diterbitkan perusahaan general syariah insurance pada website perusahaan periode 2013-2017 maka Jenis data yang dipakai dalam reserch ini adalah data sekunder.

Tujuan reserch ini berfokus untuk membuktikan dan apakah terjadi korelasi antara variabel independent yaitu premium income (X1) Underwriting result (X2) Investment income (X3) dan Risk based capital (X4) dan variabel dependent atau profit dari perusahaan general syariah insurance (Y) pada insurance company yang listing di OJK. Populasi dalam research ini adalah seluruh asuransi umum syariah yang listing di ojk pada 20132017, yaitu sebanyak 3 perusahaan merupakan full general syariah insurance dan 25 perusahaan merupakan unit syariah dari general insurance.

Metode pemilihan sampling yang dipakai dalam research ini adalah purposive sampling metode, yaitu merupakan teknik pengambilan sampel yang infomasinya diperoleh dengan kriteria-kriteria tertentu. sampling pada research ini sebanyak 15 perusahaan. Teknik analisis data dalam research ini adalah analisis regresi data panel yang diolah dengan aplikasi Eviews-7.0. Analisis tersebut meliputi estimasi model regersi data panel, pemilihan model regresi data panel ( chow test dan hausmant test) dan untuk uji hipotesis atau Goodness of fit meliputi Uji t (Partial test) dan Uji F (Simultan test) serta Koefisien determinasi (Widarjono, 2007).

\section{HASIL DAN PEMBAHASAN}

Analisis statistik deskriptif

Analisis ini ditujukan untuk mengetahui gambaran Premium income, Underwriting result, Invesment Income dan Risk based capital on general syariah insurance company's profit in indonesia yang di konversikan secara eksternal , dengan memberikan gambaran dari perbandingan keadaan rata rata perusahaan dengan ojek atau sebuah perusahaan.

Tabel 1 : Statistik Deskriptif

\begin{tabular}{|c|c|c|c|c|c|}
\hline & LB (Y) & $\mathrm{PP}(\mathrm{X} 1)$ & $\begin{array}{l}\mathrm{HU} \\
(\mathrm{X} 2)\end{array}$ & HI (X3) & $\begin{array}{l}\text { RBC } \\
(\mathrm{X} 4)\end{array}$ \\
\hline Mean & $\begin{array}{c}22312 . \\
24\end{array}$ & $\begin{array}{c}329189 \\
7 .\end{array}$ & $\begin{array}{c}330203 . \\
2\end{array}$ & $\begin{array}{c}339864 . \\
2\end{array}$ & $\begin{array}{c}2.3701 \\
33\end{array}$ \\
\hline Median & $\begin{array}{c}7875.0 \\
00\end{array}$ & $\begin{array}{c}107872 . \\
0\end{array}$ & $\begin{array}{c}15379.0 \\
0\end{array}$ & $\begin{array}{c}11813.0 \\
0\end{array}$ & $\begin{array}{c}0.9100 \\
00\end{array}$ \\
\hline Maximum & $\begin{array}{c}234240 \\
.0\end{array}$ & $\begin{array}{c}732751 \\
99\end{array}$ & $\begin{array}{c}844276 \\
3 .\end{array}$ & $\begin{array}{c}735941 \\
3 .\end{array}$ & $\begin{array}{c}24.570 \\
00\end{array}$ \\
\hline Minimum & -29418 & -21419 & -14457 & -2999 & $\begin{array}{c}0.0100 \\
00\end{array}$ \\
\hline Std. Dev. & $\begin{array}{c}42832 . \\
38\end{array}$ & $\begin{array}{c}115320 \\
3\end{array}$ & $\begin{array}{c}118896 \\
0\end{array}$ & $\begin{array}{c}126839 . \\
1\end{array}$ & $\begin{array}{c}4.3363 \\
46\end{array}$ \\
\hline Sum & $\begin{array}{c}167341 \\
8 .\end{array}$ & $\begin{array}{c}2.47 \mathrm{E}+ \\
08\end{array}$ & $\begin{array}{c}247652 \\
37\end{array}$ & $\begin{array}{c}254898 \\
15\end{array}$ & $\begin{array}{c}177.76 \\
00\end{array}$ \\
\hline $\begin{array}{l}\text { Sum Sq. } \\
\text { Dev. }\end{array}$ & $\begin{array}{c}1.36 \mathrm{E}+ \\
11 \\
\end{array}$ & $\begin{array}{c}9.88 \mathrm{E}+ \\
15 \\
\end{array}$ & $\begin{array}{c}1.05 \mathrm{E}+ \\
14\end{array}$ & $\begin{array}{c}1.19 \mathrm{E}+ \\
14\end{array}$ & $\begin{array}{c}1391.4 \\
88\end{array}$ \\
\hline $\begin{array}{l}\text { Observati } \\
\text { ons }\end{array}$ & 75 & 75 & 75 & 75 & 75 \\
\hline
\end{tabular}

Sumber : Data diolah Eviews 7

Berdasarkan hasil olah statistik deskriftif pada tabel 5.1, terlihat bahwa simpangan data pada net profit (Y) kurang baik, karena dengan nilai rata rata laba bersih (LB) selama periode 2013-2017 sebesar 22312.24 dengan standar devisiasi sebesar 42832.38 lebih besar dari mean hal ini mendeskripsikan laba bersih memiliki sebaran data besar.

Pada Variabel $\mathrm{X}_{1}$ Pendapatan Premi (PP) simpangan data baik, nilai rata rata pendapatan premi $\left(\mathrm{X}_{1}\right)$ selama periode 2013-2017 sebesar 3291897 dengan standar 
devisiasi 1153203 lebih kecil dari mean. Hal tersebut mendeskripsikan premium income $\left(\mathrm{X}_{1}\right)$ memiliki sebaran data yang kecil.

Selanjutnya Pada Variabel $\mathrm{X}_{2}$ Hasil Underwriting (HU) simpangan data cukup baik, nilai rata rata Hasil underwriting $\left(\mathrm{X}_{2}\right)$ selama periode 20132017 sebesar 330203.2 dengan standar devisiasi 118896.0 lebih kecil dari mean. Hal tersebut mendeskripsikan Underwriting result $\left(\mathrm{X}_{2}\right)$ memiliki sebaran data yang kecil.

Kemudian Pada Variabel $\mathrm{X}_{3}$ Hasil Investasi (HI) ) simpangan data cukup baik, nilai rata rata Hasil Investasi $\left(\mathrm{X}_{3}\right)$ selama periode 2013-2017 sebesar 339864.2 dengan standar devisiasi 1126839.1 lebih kecil dari mean. Hal tersebut mendeskripsikan Invesment Income $\left(\mathrm{X}_{3}\right)$ memiliki sebaran data yang kecil.

Kemudian Variabel selanjutnya $\mathrm{X}_{4}$ Risk Based Capital (RBC) memiliki simpangan data kurang baik, nilai rata rata Risk Based Capital $\left(\mathrm{X}_{4}\right)$ selama periode 2013-2017 sebesar 2.370133 dengan standar devisiasi sebesar 4.336346 lebih besar dari mean. Hal tersebut mendeskripsikan RBC $\left(\mathrm{X}_{4}\right)$ memiliki sebaran data yang besar.

Analisis Regresi Data Panel

Pemilihan Model (Teknik Estimasi) Regresi Data Panel

Menurut Widarjono (2007:251) terdapat 3 model statistik data panel, yaitu Common effect mode merupakan teknik dengan menggabungkan antara cross section dengan time series serta cross section dengan Ordinary Least Square (OLS) methode, teknik tersebut adalah yang paling sederhana untuk memperkirakan data panel, yaitu kemudian Pendekatan Model Fixed Effect memperkirakan bahwa intersep dari setiap individu adalah berbeda sedangkan slope antar individu adalah tetap (sama), dan yang ke tiga Estimasi data panel dengan model Randome Effect mengasumsikan setiap perusahaan mempunyai perbedaan intersep, yang mana intersep tersebut adalah variabel random atau stokastik. Setelah dilakukan pemilihan model regresi data panel maka yang tepat di gunakan adalah model fixed effect, sebagai berikut:

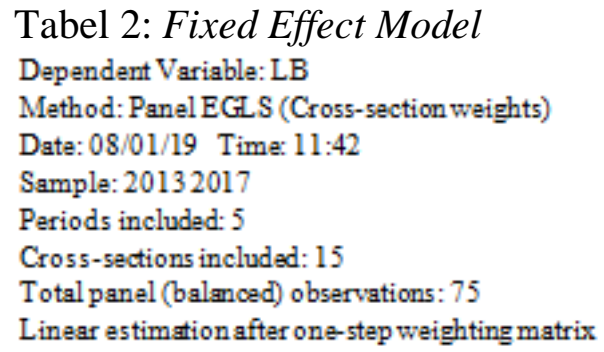

Sumber : Data di olah Eviews 7

Untuk mengetahui lebih lanjut, apakah model fixed effect tepat di gunakan, maka akan lakukan Uji Chow atau Uji F (Fixed vs Common) dan Uji hausman. Hasil uji Chow ini digunakan untuk mengetahui manakah lebih baik, regresi data panel tanpa variable dummy dengan common effect mode. Berikut hasil uji chow ( Uji Statistik F) dengan Reduntdant Test. Berikut Hipotesis nul dari uji Chow adalah 
sebagai berikut :

Ho : Common effect Model

H1 : Fixed effect Mod

Tabel 3: Uji Chow

Redundant Fixed Effects Tests

Equation: FIXED

Test cross-section fixed effects

\begin{tabular}{lll}
\hline \hline Effects Test Statistic & d.f. & Prob. \\
\hline \hline $\begin{array}{l}\text { Cross- } \\
\text { section F }\end{array}$ & 7.170384 & \\
\hline
\end{tabular}

Sumber : Data diolah Eviews 7

Dari hasil output Chow test dapat dilihat Jika Prob. > 0,05 maka Ho diterima dan model yang terpilih adalah common effect, Tetapi jika Prob. $<0,05$ maka $\mathrm{H}_{1}$ diterima dan model yang terpilih adalah fixed effect Model . dari Tabel 5.2 terlihat nilai Prob. Cross-section F 0,0000 < 0,05 sehingga dapat disimpulkan bahwa $\mathrm{H}_{1}$ diterima, dan hal ini mengindikasikan fixed effect Mode adalah model yang paling tepat dipakai dalam research ini. Model ini dapat dilihat pada tabel 5.3.

Selanjutnya dilakukan lagi Uji Hausman (Fixed vs Random) Pada uji dipakai untuk menentukan yang mana yang lebih baik dari fixed effect mode dan Random effect mode lebih baik dari Common effect mode. Berikut hasil uji Hausman (Uji Statistik F) dengan Hausman Test. Hipotesis nul dari uji hausman adalah sebagai berikut :

Ho : Random effect Model

$\mathrm{H}_{1}$ : Fixed effect Model

Tabel 4: Uji Hausman

Correlated Random Effects - Hausman Test

Equation: RANDOM

Test cross-section random effects

\begin{tabular}{llll}
\hline \hline & & Chi-Sq. & \\
Test Summary & Chi-Sq. Statistic & d.f. & Prob. \\
\hline \hline $\begin{array}{l}\text { Cross-section } \\
\text { random }\end{array}$ & 1.013012 & 4 & 0.9078 \\
\hline \hline
\end{tabular}

Sumber : Data diolah Eviews 7
Dari hasil output dengan Hausman test tersebut terlihat apabila probabilitas cross section $>0,05$ maka Ho diterima dan model yang tepat adalah Random effect, Tetapi jika prob. Cross section $<0,05$ maka $\mathrm{H}_{1}$ diterima dan model yang tepat adalah fixed effect Model . Pada Tabel 5.3 dapat dilihat bahwa nilai Prob. Cross- section Random 0,9078>0,05 sehingga dapat disimpulkan bahwa Ho diterima, dimana model yang tepat digunakan adalah Random Effect Mode.

Berdasarkan Pengujian yang dilakukan sebelumnya dari Chow test dan Hausman Test, dapat dilihat bahwa uji Chow menunjukkan fixed effect mode lebih tepat digunakan tetapi pada uji Husman menunjukkan randome effect mode lebih tepat digunakan. Namun dari probabilitas pada Chow test lebih baik yaitu 0,0000 dibandingkan pada Hausman test lebih tinggi sebesar 0,9078. Maka dalam persamaan ini, model yang digunakan dalam mengestimasi model yang tepat adalah Fixed Effect Mode, dan model ini dapat di lihat pada tabel 5.3.

a. Estimasi Model Regresi Data Panel

Model persamaan regresi data panel berikut merukan mix dari data time series dan cross section:

$Y_{i t}=\alpha+\beta_{1} X_{1 i t}+\beta_{2} X_{2 i t}+\ldots+\beta_{n} X_{n i t}+e_{i t}$

Jika hasil dari uji dimasukkan dalam persamaan regresi linear berganda, akan tercermin sebagai berikut:

$Y=3406.502+0.004602 P P-0.015417 H U$ $-0.017279 H I+6210.699 R B C$

Dari persamaan regresi linear berganda di atas, maka dapat dijelaskan bahwa:

1. Nilai Konstanta $(\alpha) \quad 3406.502$ menunjukkan bahwa $\mathrm{X}_{1}(\mathrm{PP}), \mathrm{X}_{2}(\mathrm{HU})$, $\mathrm{X}_{3}(\mathrm{HI}), \mathrm{X}_{4}(\mathrm{RBC})$ adalah Nol maka Nett profit sebesar 3406.502. 
2. Koefisien regresi Pendapatan Premi (PP) adalah positif 0.004602 artinya jika Pendapatan Premi ditambah sebesar $1 \%$ dan variabel lain tetap, hal ini dapat meningkatkan Laba sebesar 0.004602 .

3. Koefisien regresi Hasil Underwriting (HU) adalah 0.015417 artinya jika Hasil Underwriting ditambah sebesar $1 \%$ dan variabel lain tetap, hal ini dapat menurunkan Laba sebesar 0.015417 .

4. Koefisien regresi Hasil Investasi (HI) adalah 0.017279 artinya jika Hasil Investasi ditambah sebesar $1 \%$ dan variabel lain tetap, hal ini dapat menurunkan Laba sebesar 0.017279.

5. Koefisien regresi Risk Based Capital (RBC) adalah 6210.699 artinya jika Risk Based Capital ditambah sebesar $1 \%$ dan variabel lain tetap, hal ini dapat meningkatkan Laba sebesar 6210.699

d. Uji Kelayakan (Goodness of Fit) Model Regresi Data Panel / Uji Hipotesis.

1. Uji-t (pengujian koofisien secara Parsial)

Dengan asumsi variabel lain konstanta pada uji ini dilakukan untuk melihat signifikansi secara partial antara variabel dependen dengan variabel independen. Pada output fixed effect mode atau pada tabel 5.3 hasil uji $\mathrm{T}$ dapat dilihat secara langsung.

jika probabilitas $>0,05 \quad(\alpha)$ maka variabel independen secara individu tidak mempengaruhi integritas laporan keuangan, tetapi jika kecil dari 0,05 maka variabel bebas secara individu mempengaruhi integritas laporan keuangan, atau:

Ho Ditolak dan H1 Diterima jika Probabilitas - sig $<(\alpha)=5 \%$
$\mathrm{H}_{1}$ Ditolak dan Ho Diterima jika, Probabilitas $-\operatorname{sig}>(\alpha)=5 \%$

a. Variabel Pendapatan Premi (PP) terhadap Laba Bersih

Dari hasil output dapat dilihat tingkat prob-signifikansi pendapatan premi (PP) $0,0000<0,05$ dan $t$ Statistik sebsar 6.346736 , Maka $\mathrm{H}_{1}$ diterima dan Ho ditolak . secara parsial premium income berpengaruh Positif dan signifikan terhadap nett profit hal ini menunjukkan semakin meningkat premium income maka semakin tinggi pula Laba bersih.

b. Variabel Hasil Underwriting terhadap Laba Bersih

Dari hasil output dapat dilihat tingkat prob-signifikansi Hasil Underwriting (HU) sebesar 0,0010 < 0,05 dan $t$ Statistik sebsar -3.479409, sehinga dapat disimpulkan $\mathrm{H}_{1}$ diterima dan Ho ditolak . secara parsial Underwriting result berpengaruh Negatif dan signifikan terhadap Nett Profit, yang berarti semakin tinggi Underwriting result maka akan semakin menurunkan Laba Bersih.

c. Variabel Hasil Investasi terhadap Laba Bersih

Output Hasil Investasi (HI) dapat dilihat tingkat prob-signifikansi sebesar $0,0000<0,05$ dan $t$ Statistik sebsar 4.982330, sehingga $\mathrm{H}_{1}$ diterima dan $\mathrm{Ho}$ ditolak . secara parsial Invesment income berpengaruh Negatif dan signifikan terhadap Laba Bersih, hal ini menunjukkan dengan meningkatnya hasil investasi maka akan semakin menurunkan laba bersih.

d. Variabel Risk Based Capital terhadap laba bersih 
Output Risk Based Capital (RBC) dapat dilihat tingkat prob-signifikansi sebesar $0,0000<0,05$ dan $t$ Statistik sebsar 7.864924, Hal ini menunjukan bahwa $\mathrm{H}_{1}$ diterima dan $\mathrm{Ho}$ ditolak secara parsial RBC berpengaruh Positif dan signifikan terhadap Nett profit yang berati semakin tinggi Risk Based Capital maka akan semakin tinggi pula nett profit.

2. Uji-F (pengujian koofisien secara Simultan)

Test ini ditujukan untuk mengetahui pengaruh variabel dependepen apakah secara bersama sama (Simultan) memiliki pengaruh terhadap variabel Dependen . Untuk menunjukkan apakah masing masing variabel independen berpengaruh terhadap variabel dependen maka $\mathrm{F}$ hitung dari koefisien di bandingkan dengan $\mathrm{F}$ tabel dengan probabilitas sig. $<(\alpha)=5 \%$. Untuk hasil Uji $F$ dapat dilihat langsung pada hasil output pemilihan model Fixed Effect pada tabel 5.3.

Ho $=$ Premium Income, Underwriting result, Investmen income dan Risk Based Capital tidak berpengaruh terhadap Laba Perusahaan asuransi umum syariah.

$\mathrm{H}_{1}=$ Premium Income, Underwriting result, Investmen income dan Risk Based Capital berpengaruh terhadap Laba Perusahaan asuransi umum syariah.

Dengan kriteria sebagai berikut:

a) Jika $F_{\text {hitung }}>F_{\text {tabel }}$ maka Ho Ditolak dan $\mathrm{H}_{1}$ diterima

b) Jika $\mathrm{F}_{\text {hitung }}<\mathrm{F}_{\text {tabel }}$ maka Ho Diterima dan $\mathrm{H}_{1}$ ditolak

Dari output diatas terlihat nilai $\mathrm{F}$ hitung sebesar 822,6251. Output tersebut di tentukan dengan $\operatorname{df} 1(\mathrm{n} 1)=$
4 dan df2 (n2)= 70 maka hasil $F$ tabel adalah 2,50. Maka dapat dijelaskan bahwa F hitung 822,6251 > F tabel 2,50, dengan prob -sig $0,000000<0.05$, sehingga maka model regresi dapat digunakan untuk memprediksi variabel dependen laba bersih, atau secara bersama sama Variabel Independen Pendapatan premi (PP), Hasil Underwriting (HU), Hasil Investasi (HI) dan Risk based Capital (RBC), berpengaruh terhadap Variabel Dependen yaitu Nett Income. Jadi Kesimpulan yang dapat ditarik Ho ditolak dan $\mathrm{H}_{1}$ diterima.

3. Koefisien Determinasi

Nilai Koefisien Determinasi mencerminkan seberapa besar variasi dari variabel terikat dapat diterangkan oleh variabel bebasnya. Bila nilai Koefisien Determinasi sama dengan 0 , artinya variasi dari variabel terikat tidak dapat diterangkan oleh variabel-variabel bebasnya sama sekali. Sementara bila nilai Koefisien Determinasi sama dengan 1, artinya variasi variabel terikat secara keseluruhan dapat diterangkan oleh variabel-variabel bebasnya.

Dari output dapat dilihat bahwa nilai Adj R - square adalah 0.995021, Hal ini menunjukkan variasi dari keempat variabel Independen Pendapatan premi (PP), Hasil Underwriting (HU), Hasil Investasi (HI) dan Risk based Capital (RBC) dapat menjelaskan 99,50\% variasi Laba Bersih. Sedangkan sisanya $(100 \% \quad-\quad 99,50 \%)$ sebesar $0,50 \%$ dideskripsikan oleh variabel di luar model penelitian.

Pengaruh Pendapatan Premi Terhadap Laba Bersih

Dalam Asuransi syariah pendapatan premi berarti sejumlah dana yang terdiri dari Dana tabungan dan dana Dana tabbaru'yang dibayarkan oleh peserta. Premi adalah biaya yang dibebankan suatu perusahaan asuransi untuk jumlah uang 
pertanggungan tertentu.Tarif premi harus adequate (memadai) untuk dapat memenuhi manfat dari polis asuransi. Dari hasil output dapat dilihat tingkat probsignifikansi pendapatan premi (PP) sebesar $0,0000<0,05$ dan $t$ Statistik sebsar 6.346736 , Maka dapat disimpulkan bahwa variable premi berpengaruh positif signifikan terhadap laba bersih.

Teori akuntansi menerangkan bahwa, konsep pendapatan merupakan peningkatan nilai aset dari suatu entity atau penyelesaian kewajiban dari suatu entity, Oleh karena itu faktor utama bagi laba perusahaan merupakan pendapatan premi atau Premium income. Untuk meningkatkan laba tentu harus diiringi dengan pendapatan premi yang memadai. sebaliknya jika laba rendah hal tersebut mengindikasikan lemahnya pendapatan premi. Dari Hasil analisis dapat dijelaskan bahwa Hal ini sejalan dengan hasil reserch yang dilakukan oleh Putri Imanda (2017) dengan judul impect of claim, premium, Invesment Income dan Operatig cost on general syariah insurance companies asset growth, dan penelitian Sastri, dkk (2017) dengan judul Impect of Premium income, Underwriting result, Investmen Income and Risk Based Capital on insurance companies' net profit

Pengaruh Hasil Underwriting Terhadap Laba

Underwriting result or
underwriting income is the eraned
premium remaining, it is the difference
between tabbaru' premiums and claims
paid out and expanses a periode of time,
but if underwriting loss of premium its
mean deficit Underwriting (Juwita;2017).
Berdasarkan teori menjelaskan bahwa
Underwriting dimaksudkan untuk
memaksimalkan laba melalui penerimaan
resiko dengan penaksiran mortalitas dan
morbiditas calon tertanggung.

Underwriting bertujuan untuk mendapatkan laba yang setinggi tinggi nya dari pengcoveran resiko underwriting yang baik dan effesien membuat perusahaan asuransi siap berkompetisi. Dan untuk memaksimalkan konsumen pada perinsipnya resiko baik ( menguntungkan) dan resiko yang kurang baik harus seimbang dalam kategori yang layak untuk diasuransikan. Dari hasil output dapat dilihat tingkat prob-signifikansi Hasil Underwriting (HU) sebesar 0,0010 < 0,05 dan $t$ Statistik sebsar -3.479409, Maka secara partial Hasil Underwriting meiliki pengaruh Negatif dan signifikan terhadap Net profit.

Dan yang harus dilakukan Underwriting dalam pemilihan resiko adalah memilah dengan baik risiko yang benar-benar membawa keuntungan dan terbebas dari kesulitan yang mungkin akan dihadapi perusahaan. Tujuan underwriting juga untuk meminimalisir pertanggungan yang tidak seimbang antara resiko ringan dan berat, bukan hanya memilih resiko yang mendatangkan kerugian saja. Dengan demikian, diusahakan menyamakan kerugian-kerugian yang aktual dengan kerugian harapan.

Pembayaran santunan atau klaim akan membengkak jika perusahaan asuransi gagal dalam memilih dan mengcover banyak resiko meragukan dengan premi yang tidak sesuai. Dengan demikian apabila perusahaan asuransi mengcover resiko yang tidak baik dengan premi yang tidak memadai, maka perusahaan asuransi tidak dapat mendatangkan laba bersih yang maksimal pula. Untuk itu di harapkan Underwriter dapat lebih selektif dalam memilih resiko atau mengambil resiko dengan pertanggungan secara bersama sama ( share risk) dengan beberapa asuransi lain atau Co-Insured atau Reasuransi . Uraian tersebut selaras dengan yang diteliti oleh Indriyani (2015) menunjukkan Hasil Underwriting berpengaruh negatif signifikan terhadap laba bersih asuransi. 
Pengaruh Hasil Investasi Terhadap Laba

Hasil investasi adalah kegiatan menanamkan modal seperti uang dan harta dengan tujuan imbalan keuntungan pembagian hasil investasi yang diserahkan kepada pemilik dana dalam hal ini yaitu pengelola dan peserta asuransi. Peserta asuransi ( Pemilik dana) dan pengelola dana ( pihak asuransi) akan mendapatka hasil dari investasi, dan selisihnya akan di sharing menurut prinsip mudharabah (Supiyanto; 2015; 33). Dari hasil output dapat dilihat tingkat prob-signifikansi Hasil Investasi (HI) sebesar 0,0000 < 0,05 dan $t$ Statistik sebsar -4.982330, Maka dapat disimpulkan bahwa secara parsial Hasil Investasi berpengaruh Negatif dan signifikan terhadap Laba Bersih.

Sesuai prinsip Investasi asuransi syariah, bagi peserta yang tidak menggunakan manfat polis asuransi manfaat akan di kembalikan, akan tetapi bagi perusahaan atau pengelola dana keuntungan digunakan untuk membayar operasional perusahaan, sehingga pergerakan laba sangat dipengaruhi oleh tingkat investasi (Ichsan, 2014). Jika hasil investasi meningkat tetapi diiringi nilai operasional yang tidak terkendalali seperti klaim yang tinggi maka hasil investasi akan dicadangkan dalam klaim sehingga menyebabkan laba bersih yang tidak maksimal. Untuk itu perusahaan di harapkan dapat mengontrol dan meminimalisir nilai terbesar dalam operasional perusahaan asuransi seperti pembayaran claim. Estimator claim dan team analist claim lebih selektif dalam memutuskan nilai claim yang harus di bayar perusahaan. Selaras dengan reserch yang dilakukan oleh Arum Fajarwati (2018) mendapatkan Hasil Investasi berpengaruh negatif signifikan terhadap net profit asuransi.
Pengaruh Risk Based Capital Terhadap Laba

RBC merupakan ukuran kesehatan financial perasuransian. Semakin tinggi rasio kesehatan $\mathrm{RBC}$ maka akan mendatangkan laba yang baik dan hal tersebut mencerminkan kesehatan finansial atau keuangan perusahaan asuransi tersebut seiring dengan hal tersebut maka laba yang di peroleh juga akan meningkat (Bogar; 2016; 65). Kententuan pemerintah tentang Risk Based Capital atau batas solvabilitas akan menghambat tujuan perusahaan dalam memaksimalkan laba melalui pendapatan premi dari peserta. Hal yang mungkin dihadapi perusahaan adalah trade off terhadap pengcoveran risiko, baik risiko investasi maupun underwriting. RBC merupakan batas tingkat solvabilitas minimum yang harus dicapai oleh setiap perusahaan asuransi dan reasuransi wajib memiliki batas solvabilitas (RBC) paling rendah $120 \%$ yang berarti bahwa hutang perusahaan dan biaya setiap resiko asuransi yang di tanggung wajib ditutupi dengan minimal $20 \%$ lebih besar dari aset perusahaan.

Dari output dapat dilihat tingkat prob-signifikansi Risk Based Capital (RBC) sebesar 0,0000 < 0,05 dan $t$ Statistik sebsar 7.864924, Maka dapat disimpulkan bahwa secara parsial RBC berpengaruh Positif dan signifikan terhadap Laba Bersih. Hal ini selaras dengan reserch yang ditunjuk kan oleh Sastri, dkk (2017) Risk based capital berpengaruh positif signifikan terhadap laba asuransi. Hal ini mencerminkan perusahaan dapat memenuhi dan melunasi hutang jangka panjang nya. Penelitian Mutmainnah (2015) menemukan pengaruh positif antara risk based capital terhadap laba asuransi. Untuk memberikan kepercayaan pada masyarakat perusahaan harus mencapai batas solvabilitas yang baik dengan begitu masyarakat akan mempercayakan asetnya pada jasa pengcoveran asuransi jaminan terhadap harta benda, hal ini berpengaruh dengan penyerapan pendapatan premi yang 
beradampak pada peningkatan laba perusahaan.

\section{KESIMPULAN DAN SARAN}

Berdasarkan hasil pengujian analisis data dan pembahasan yang telah dilakukan pada bab sebelumnya, maka dapat disimpulkan bahwa secara simultan variabel independen (Pendapatan premi,Hasil Under writing, Hasil Investasi dan Risk Based Capital) berpengaruh signifikan terhadap laba bersih perusahaan asuransi syariah di indonesia, sedangkan secara partial dapat disimpulkan bahwa Premium income variabel $\left(X_{1}\right)$ had positif significan effect on net profit. Hasil pengujian pada variabel ini sesuai dengan hipotesis pertama, Dengan tinggi nya pendapatan premi seiring dengan meningkatnya laba yang akan di peroleh perusahaan asuransi umum syariah.

Variael Underwriting Result $\left(X_{2}\right)$ had Negatif signifikan effect on net profit. Pengujian pada variabel ini selaras dengan hipotesis kedua. Semakin rendah Hasil Underwriting maka akan semakin buruk, karena memberi tingkat kembalian yang lebih kecil. Dengan pemilihan risiko yang layak untuk di cover dan diiringi dengan penerimaan premi yang tidak sebanding , maka penyerapan laba bersih juga tidak akan maksimal.

Variael Invesment income $\left(X_{3}\right)$ had Negatif signifikan effect on net profit. Hasil pengujian pada variabel ini sesuai dengan hipotesis tiga. Hasil tersebut menunjukkan jika hasil investasi meningkat tetapi diiringi nilai operasional yang tidak terkendalali seperti klaim yang tinggi maka hasil investasi akan dicadangkan dalam klaim sehingga menyebabkan laba bersih yang tidak maksimal.

Variael Risk Based capital $\left(X_{4}\right)$ had positif signifikan effect on net profit. Hasil pengujian pada variabel ini sesuai dengan hipotesis keempat. $R B C$ atau Batas tingkat solvabilitas merupakan batas tingkat solvabilitas minimum yaitu ukuran kesanggupan suatu perusahaan untuk memenuhi kewajibannya seperti hutang jangaka panjang, Untuk memberikan kepercayaan pada masyarakat perusahaan harus mencapai batas solvabilitas yang baik dengan begitu masyarakat akan mempercayakan asetnya pada jasa pengcoveran asuransi jaminan terhadap harta benda, hal ini berpengaruh dengan penyerapan pendapatan premi yang beradampak pada peningkatan laba perusahaan.

Adapun saran yang dapat diberikan dalam kajian ini antara lain:

1. Penelitian berikutnya mungkin dapat memperluas objek penelitian seperti memasukkan seluruh asuransi, baik asuransi syariah dan unit syariah maupun konvensional.

2. Penelitian berikutnya sebaiknya dapat memasukkan variabel lain yang lebih signifikan mempengaruhi laba perusahaan asuransi umum syariah di Indonesia, hal ini untuk meningkatkan pengetahuan mengenai Laba bersih khususnya pada asuransi umum syariah di Indonesia. Variabel yang mungkin dapat digunakan seperti variabel klaim dan beban operasional karena kedua variabel tersebut juga merupakan arus utama keluarnya pendapatan dan dan hal tersebut dapat mempengaruhi laba perusahaan.

3. Pada periode penelitian yang lebih panjang memungkinkan hasil analisis yang lebih baik.

4. Bagi investor, tidak hanya menggunakan ukuran moneter, dalam penelitian berikut diharapkan dapat memberikan variabel baru dalam memperhitungkan investasi.

5. Bagi masyarakat, akan memberikan edukasi tentang perasuransian khususnya pada lini syariah dan semakin memberikan kesadaran masyarakat akan pentingnya asuransi dan mengetahui 
Jurnal Ilmiah Ekonomi dan Bisnis

Vol. 17. No.1, Maret 2020 : 41-55

EISSN : $2442-9813$

ISSN : $1829-9822$

lebih baik lagi kewajiban dan hak- hak yang harus diperoleh.

\section{DAFTAR PUSTAKA}

Aprilino. A.D. (2014). Analisis Pengaruh Solvabilitas Dan Underwriting Terhadap Profitabilitas Perusahaan Asuransi Kerugian (Studi Pada Perusahaan Asuransi Kerugian Yang Listing Di Bursa Efek Indonesia Tahun 2008 - 2012). Artikel Ilmiah. Surabaya. Sekolah Tinggi Ilmu Ekonomi Perbanas.

Astria. D. (2009). Analisis Faktor-Faktor yang Mempengaruhi Laba PT. Asuransi Takaful Keluarga. Skripsi. Fakultas Ekonomi dan Manajemen. Bogor: Institut Pertanian Bogor.

Abbas,Salim. (2007).Asuransi dan Manajemen Risiko. Jakarta: PT Raja Grafindo Persada.

Belkaoui. A. R. (2011). Teori Akuntansi. Jakarta: Salemba Empat.

Bogar. S. (2016). Analisis Risk Based Capital (RBC) di Perusahaan Asuransi. JRAK. Vol. 7 No. 2

Dhaniati. R. (2011). Analisis Pengaruh $R B C$, Rasio Underwriting, Rasio Hasil Investasi, Rasio Premi, dan Rasio Beban Klaim Terhadap Laba Perusahaan Asuransi. Skripsi. Universitas Gunadarma.

Darmawi, Herman.(2011). Manajemen Asuransi. Bumi Aksara,Jakarta.

Dipoyanti.N. (2014). Pengaruh pendapatan premi, hasil investasi, Underwriting, klaim, dan beban Operasional terhadap laba asuransi Jiwa syariah di indonesia. Skripsi. Universitas Islam Negeri Sultan Syarif Kasim Riau.

Fajarwati.A. (2018). Pengaruh solvabilits premi, klaim dan investasi, terhadap pertumbuhan laba diperusahaan asuransi Umum syariah di indonesia 2012-2015. Skripsi.Universitas Islam Sunan kalijaga Yogyakarta.

Ghozali. I. (2013). Aplikasi Analisis Multivariate Dengan Program IBM SPSS 21 Update PLS Regresi Edisi 7. Yogyakarta: Badan Penerbit Universitas Diponegoro.

Gatzert,N and Schmeiser,H.(2008). Invesment Guarentees In UnitLinked Life Insurance Product: comparing Cost And performance . Woarking Papers On Riskk Managementn and Insurance No. 40 University Of St.Gallen.

Harahap. S. S. (2010). Teori Akuntansi. Edisi Revisi. Jakarta: Rajawali Pers.

Ichsan. N. (2014). Pengantar Asuransi Syariah. Jakarta: Gaung Persada Press Group.

Imam. S. Asuransi takaful kajian komparasi dengan asuransi konvensional. Artikel. Universitas Nurul Jadid Probolinggo.

Jumingan. (2011) Analisis Laporan Keuangan. Jakarta: PT Bumi Aksara

Juwita . T. (2017) . Analisis pengaruh pendapatan premi, klaim, investasi dan surplus underwriting terhadap pertumbuhan laba pada industri asuransi syariah tahun 2012 - 
2016. Skripsi . Institut Agama Islam negeri Salatiga.

Kasmir. (2012). Analisis Laporan Keuangan. Jakarta: Raja Grafindo Persada.

Karwati,Euis Lia . (2011). Metode Alokasi Surplus Underwriting Dana Tabarru' pada Asuransi Kerugian Syariah (Studi Kasus Unit Syariah PT Asuransi Umum Bumi Putra Muda 1967). Skripsi.Universitas islam Negeri Syarif Hidayatullah Jakarta.

Khotimah, Husnul . (2014). Pengaruh premi , klaim, hasil investasi, dan underwriting terhadap laba perusahaan asuransi syariah PT Asurasi sinar mas cabang syariah . Skripsi. Universitas Hasanuddin Makasar

Kontan. (2017) Kopsin Akuisisi Asuransi Takaful. diakses pada tanggal 9 Mei 2018 dari https://www.google.co.id/news/k opsin-akuisisi-asuransi-takafulumum/

Kuncoro. M. (2014). Metode Riset untuk Bisnis Ekonomi. Edisi 4. Yogyakarta: Erlangga.

Kusuma dan Rakhman. (2018). Peningkatan Keterampilan Olah Data (SPSS) Pada Mahasiswa DIII Akuntansi Politeknik Harapan Bersama Tegal. EJournal. Vol. 1 No.1.

Mardani, R. M., Assyifah, F. N., \& Susyanti, A. J. (2017). Pengaruh Premi, Klaim, Hasil Underwriting, Investasi dan Profitabilitas Terhadap Pertumbuhan Aset Pada Perusahaan Asuransi Syariah Di
Indonesia. e-Jurnal Riset Manajemen. Vol. 1 No. 1.

Monitor. (2015). Sri Mulyani Dukung Pertumbuhan Bisnis Asuransi Berbasis Syariah. diakses pada tanggal 9 Mei 2018 dari https://monitor.co.id/ekonomi/srimulyani-dukung-pertumbuhanbisnis-asuransi-berbasis-syariah/

Mutmainah. (2015). Analisis Pengaruh Pendapatan Premi, Klaim, Hasil Underwriting,Cadangan Teknis, Dan Risk Based Capital Terhadap Laba Pada 20 Perusahaan Asuransi Umum Di Indonesia Periode 2009-2013. Skripsi. Universitas Hasanuddin Makasar.

Nachrowi.M.dan Usman.H. (2006). Pendekatan populer dan praktis ekonometrika untuk Analisis Ekonomi dan Keuangan : Jakarta : Rajawali pers.

OJK. (2015). Daftar Perusahaan Asuransi Umum, Jiwa, Reasuransi, Asuransi Wajib Dan Asuransi Sosial. diakses pada tanggal 9 Mei 2018 dari

https://www,ojk,go,id/id/kanal/ikn b/berita-dan-

kegiatan/publikasi/Pages/DaftarPerusahaan-Asuransi-Umum,Jiwa,-Reasuransi,-Asuransi-WajibDan-Asuransi-Sosial,aspx

O. P. Simorangkir. (2004). Pengantar Lembaga Kuangan Bank dan Non Bank. Bogor Selatan: Ghalia Indonesia.

Rahayu. D. (2017). Pengaruh Risk Based Capital Terhadap Profitabilitas Perusahaan Asuransi Syariah (Studi Pada Perusahaan Asuransi Yang Terdaftar di AASI). J- 
Jurnal Ilmiah Ekonomi dan Bísnis

Vol. 17. No.1, Maret $2020: 41-55$

EISSN : $2442-9813$

ISSN : $1829-9822$

Economic. Vol. 3 No. 2. Hlm. 189-208.

Sari. (2017). Pengaruh Hasil Investasi, Underwriting, Dan Rasio Solvabilitas Terhadap Laba Perusahaan Asuransi Jiwa Syariah Di Indonesia (Periode 2011-2015). Skripsi. Universitas Islam Negeri Syarif Hidayatullah.

Sartono. A. (2014). Manajemen Keuangan Teori dan Aplikasi. Yogyakarta: Universitas Gajah Mada.

Sastri, I. A. I. P., Sujana. E., dan Sinarwati. N. K. (2017). Pengaruh Pendafatan Premi, Hasil Underwriting, Hasil Investasi Dan Risk Based Capital Terhadap Laba Perusahaan Asuransi (Periode 2011 - 2015). e-Jurnal S1 Akuntansi Universiatas Pendidikan Ganesha.

Sensi. L. (2006). Memahami Akuntansi Kerugian. Jakarta: Gramedia Pustaka.

Septian. A. (2013) Hukum Perbankan Syariah I. Jakarta: Sinar Grafika Offset.

Soemarsono. (2004). Akuntansi Suatu Pengantar. Jilid Satu. Jakarta: Salemba Empat.

Sugiyono (2013). Motedologi Penelitian Kuantitatif, Kualitatif dan $R \& D$. Bandung: Alfabeta.

Suhendi. H. dan Yusup. D. K. (2005). Asuransi Takaful, Dari Teoretis ke Praktis. Bandung: Mimbar Pustaka.

Sujarwanto. 2018. Perbandingan Antara Asuransi Syariah dan Asuransi
Konvensional. Artikel Ilmiah. Universitas Gunadarma.

Sula. M. S. (2014). Asuransi Syariah (Life And General) Konsep dan Sistem Operasional. Jakarta: Gema Insani.

Supiyanto. A. T. (2015). Pengaruh Pendapatan Premi Dan Hasil Investasi Terhadap Cadangan Dana Tabarru' Pada Perusahaan Asuransi Syariah Di Indonesia. Skripsi. Universitas Negeri Yogyakarta.

Suud. C. (2016). Pengaruh Underwriting Dan Solvabilitas Terhadap Laba Perusahaan Reasuransi. Skripsi. Universitas Lampung.

Suwardjono. (2010). Teori Akuntansi: Pengungkapan dan Sarana Interpretatif. Edisi Ketiga. BPFE. Yogyakarta: Ikatan Akuntan Indonesia.

Syahyunan. (2004) Manajemen Keuangan I (Perencanaan, Analisis dan Pengendalian Keuangan. Medan: USU Press.

Thohari. F. (2011). Menyoal Asuransi Konvensional Versus Asuransi Syariah. e-Journal. Vol. 3 No. 2. Hlm. 273-292.

Undang-Undang Republik Indonesia No. 2 Tahun 1992.

Undang-Undang Republik Indonesia No, 40 Tahun $2014 \quad$ Tentang Perasuransian.

Voaislam. (2014) Takaful Masuk 'ICU' Aseng \& Asing: Setelah Bank Muamalat, Giliran Asuransi Takaful dilego. diakses pada tanggal 13 Mei 2018 dari 
http://www.voa-

islam.com/read/syariahbiz/2014/

12/09/34393/takaful-masuk-icu-

aseng-asing-setelah-bank-

muamalat-giliran-asuransi-

dilego/\#sthash.yGgBulme.dpbs

Widarjono, Agus. (2007). Ekonomi teori dan aplikasi. Yogyakarta : Ekonisia FE UII

Winwin Yadiati. (2007). Teori Akuntansi:

Suatu Pengantar. Jakarta:

Kencana

Yusuf. T. O., dan Dansu. F. S. (2014). Effect of Claim Cost on Insurer"s Profitability in Nigeria, International Journal of Business and Commerce. e-Journal. Vol. 3 No. 10 